\title{
IMPACT OF PACLOBUTRAZOL ON THE GROWTH AND DEVELOPMENT OF NURSERY GROWN CLONAL OIL PALM (Elaeis guineensis Jacq.)
}

\section{MOHD NASRIQ HAFIZEE ABDUL RAHMAN*; NOOR AZMI SHAHARUDDIN**; NURNIWALIS ABDUL WAHAB*; PUTERI EDAROYATI MEGAT WAHAB*; MEILINA ONG ABDULLAH*; NUR ASHIKIN PSYQUAY ABDULLAH‡; GHULAM KADIR AHMAD PARVEEZ*; JEREMY A ROBERTS ${ }^{\ddagger}$ and ZUBAIDAH RAMLI*}

\begin{abstract}
The economic life of an oil palm (Elaeis guineensis Jacq.) plant is associated with the stature of the palm as the height of each oil palm affects the cost of harvesting. Shorter palm allows ease of harvesting and better fruit recovery hence contributes to the increase of the fresh fruit bunch (FFB) yield. This study was conducted to investigate the effect of paclobutrazol (PBZ), an inhibitor of gibberellin (GA) biosynthesis, on the growth and development of clonal oil palms maintained under nursery conditions. Application of PBZ significantly reduced the growth of clonal palms with the optimal concentration of PBZ being $50 \mathrm{mg}$

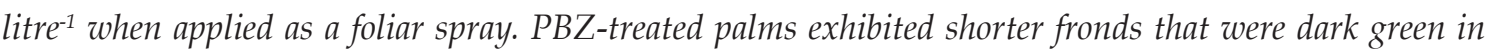
colour and plants had a more compact structure as compared to untreated controls. Longitudinal sections of PBZ-treated oil palm clones revealed that both leaves and stems comprised of fewer cells each with a smaller volume. PBZ-treated plants exhibited a higher rate of photosynthesis compared to controls and this was correlated with an accumulation of starch in stem cells. These results provide evidence that the vegetative growth of oil palm is regulated by GA levels and that by manipulating the concentration of these hormones it may be possible to attenuate the oil palm height and ultimately increase productivity.
\end{abstract}

\section{Keywords: oil palm, paclobutrazol, gibberellins, photosynthesis, plant anatomy, growth}

Date received: 15 May 2016; Sent for revision: 4 June 2016; Received in final form: 25 October 2016; Accepted: 26 October 2016.

\section{INTRODUCTION}

The Malaysian palm oil industry is facing a rising production costs. Productivity of the oil palm crop is dependent on a range of factors uppermost of which is the interaction between the genotype

* Malaysian Palm Oil Board, 6 Persiaran Institusi, Bandar Baru Bangi, 43000 Kajang, Selangor, Malaysia. E-mail: bai@mpob.gov.my

** Department of Biochemistry, Faculty of Biotechnology and Biomolecular Sciences, Universiti Putra Malaysia, 43400 UPM Serdang, Selangor, Malaysia.

₹ Department of Crop Science, Faculty of Agriculture, Universiti Putra Malaysia, 43400 UPM Serdang, Selangor, Malaysia.

\# Division of Plant and Crop Sciences, School of Biosciences, University of Nottingham, Sutton Bonington Campus, Loughborough, Leicestershire, LE12 5RD, United Kingdom. of the oil palm and the environment in which it is grown (Corley and Tinker, 2003). One of the key factors in determining the economic life of an oil palm plant is the height of the oil palm as this ultimately influences both the cost of harvesting and the fresh fruit bunch (FFB) recovery and ultimately yield. An oil palm can grow to over $20 \mathrm{~m}$ tall and fruit harvesting is achieved by excising the bunch at its point of attachment and then allowing it to fall, under its own weight, to the ground. As bunches may weigh in excess of $25 \mathrm{~kg}$, this method leads to substantial damage of the ripe fruits and the extent of spoilage increases proportionally with plant height thus decreasing fruit quality.

Over the last hundred years, there has been a concentrated effort to reduce the height of many 
crops. Breeding programmes have been initiated in order to select for dwarf material and this 'green revolution' has resulted in a steady increase in the yield of cereals by reducing the quantity of assimilates partitioned into stem tissue (Itoh et al., 2002; Monna et al., 2002; Sasaki et al., 2002; Sakamoto et al., 2003). Some effort has been made to reduce the height of oil palm through conventional breeding and the Deli dumpy material, which is the best 'dwarf' germplasm currently available, has a growth rate of $40 \mathrm{~cm} \mathrm{yr}^{-1}$ compared to the standard $\mathrm{D} \times \mathrm{P}$ planting material of $50-75 \mathrm{~cm} \mathrm{yr}^{-1}$ (Kushairi et al., 1999; Luyindula et al., 2005).

Several approaches have been employed to reduce the height of crops by manipulating either their endogenous gibberellin (GA) concentrations or the intracellular signalling of this plant hormone (Hedden, 2003; Daviere and Achard, 2013). GA have long been known to modulate growth and development throughout the life cycle of a plant and their biosynthetic and catabolic pathways are now well characterised (Hedden and Phillips, 2000; Olszewski et al., 2002; Sun and Gubler, 2004; Thomas and Sun, 2004; Fleet and Sun, 2005). One of the most well-known functions of GA is to regulate vegetative growth, including the elongation of stem internodes and the expansion of leaves (Hedden, 2003).

It has been shown that by reducing the flow of carbon skeletons through the GA biosynthetic pathway or by increasing the rate at which active GA are broken down, it is possible to reduce the internodal elongation of a range of material including crop plants. The use of growth retardants such as paclobutrazol (PBZ) or cycocel (CCC), that have been documented to inhibit GA biosynthesis (Rademacher, 2000), and these chemicals have been employed successfully to reduce the height of several crop species (Berova and Zlatev, 2000; Senoo and Isoda, 2003; Haque et al., 2007) including date palm (Cohen et al., 2013). Both PBZ and CCC have been shown to inhibit internodal elongation without affecting the size of either the flower or the grain. Indeed, it has been reported that the application of PBZ to tomato seedlings not only resulted in both a reduction of plant height and increased stem thickness of young plants but also contributed to an enhancement of seedling quality at planting (Berova and Zlatev, 2000).

In this study, we have explored the impact of PBZ on the growth of clonal oil palm and examined the consequences of this growth inhibitor on their anatomy and physiology.

\section{MATERIALS AND METHODS}

\section{Plant Materials and Maintenance}

Plant materials were obtained from a fourmonth old oil palm tissue culture clone. The clonal palms were maintained under nursery conditions at a temperature of $25^{\circ} \mathrm{C}$ to $30^{\circ} \mathrm{C}$ and the mean relative humidity of $70 \%$ in tissue culture nursery at the Malaysian Palm Oil Board (MPOB), Bandar Baru Bangi, Selangor, Malaysia. Each of the clonal oil palms was grown in a polythene bag $(38 \times 16 \mathrm{~cm})$ containing a commercial potting mixture (Silicon 23, Fooktien Group). The palms were fertilised once a month at a rate of $42 \mathrm{~g}$ per palm with nutrient of $\mathrm{N}: \mathrm{P}_{2} \mathrm{O}_{5}: \mathrm{K}_{2} \mathrm{O}: \mathrm{MgO}$ at a ratio of 15:15:6:4. Water was supplied on a daily basis using a water sprinkler between 08.30 am $-17.30 \mathrm{pm}$.

\section{Experimental Treatments}

Two months after planting in a polybag (when the oil palm plantlet reached 6-month old) they were treated with one of several concentrations of PBZ (10 mg litre ${ }^{-1}, 25 \mathrm{mg}$ litre $^{-1}, 50 \mathrm{mg}$ litre $^{-1}$ or 100 $\mathrm{mg}$ litre $\left.^{-1}\right)$. Control oil palm plantlets were treated with tap water. PBZ was applied until run off once a week, for duration of six weeks, as a foliar spray.

\section{Experimental Design and Data Analysis}

The design of the experiments was complete randomised design (CRD) that comprised of five replications in each treatment. All data collected from the experiment were analysed using analysis of variance (ANOVA) with Statistical Analysis System (SAS) software Version 9.3 (SAS Institute Inc. 2013). The differences between means of separation were compared using Least Significant Difference (LSD) $(\mathrm{P} \leq 0.05)$.

\section{Growth and Physiological Changes}

This study focused on two main parameters in order to evaluate the effect of PBZ on the oil palm growth. The plant height and stem diameter were recorded every week for a period of 14 weeks after the first PBZ treatment was applied in order to determine the growth pattern of oil palm in response to the growth retardant. For physiological parameters, relative chlorophyll index, net photosynthesis rate, stomatal conductance, and transpiration rate were measured in order to determine the effect of PBZ on the physiological characteristics of the treated oil palms.

\section{Plant Height and Stem Diameter Measurement}

The oil palm height was recorded a week after the PBZ treatment ended (six times applications). The plant height was measured from the base of the plant to the highest tip of the leaves using a measuring tape. Stem diameter was recorded using a Vernier calliper at a height $5 \mathrm{~cm}$ from the plant base. 


\section{Relative Chlorophyll Index}

The measurement of relative chlorophyll index in this study was conducted using a SPAD502 meter (Konica Minolta Optic, Inc, Japan). The SPAD meter provides an alternative method for the measurement of relative leaf chlorophyll level in leaf tissues. The device is based on two light-emitting diodes and a silicon photodiode receptor that facilitates the measurement of leaf red transmittance, and the infrared regions of the electromagnetic spectrum which is proportional to the amount of chlorophyll in the tested sample. The measurements of relative chlorophyll content were taken from the number three leaf from the oil palm tips betwen 09.00 - 11.00 am.

\section{Leaf Gas Exchange}

The net photosynthesis rate, stomatal conductance and transpiration rate in leaf were measured using Portable Photosynthesis System (LI-6400, LICOR Inc., USA) on the same leaves tested for their relative chlorophyll content. Prior to use, the instrument was warmed and calibrated for $30 \mathrm{~min}$ in ZERO IRGA mode. There are two steps required in the calibration process: first, initial zeroing process for the built in flow meter; and second, zeroing process for infrared gas analyser. In order to maintain the similar environmental conditions, all data were collected between 09.00 $-11.00 \mathrm{am}$.

\section{Histological Studies}

Plant samples (leaf, stem and basal stem) were collected six weeks after PBZ treatment for histological analysis using resin techniques (developed by ORSTOM-CIRAD). Plant samples of each treatment were fixed in glutaraldehydeparaformaldehyde-caffeine, tissue was dehydrated using an ethanol series (Elmar and Frank, 2010; Paiva et al., 2011; Kok et al., 2015), before infiltration and embedding in Resin LKB kit (Technovit 7100). Sections were cut using a rotary microtome (Leica system), and then stained with periodic acid, Schiff's reagent in dark, and $80 \%(\mathrm{w} / \mathrm{v})$ of naphtol blueblack solution. The stained specimen was mounted with Surgipath mounting medium before being observed under a light microscope (Leica CTR6000) for histological studies.

\section{RESULTS AND DISCUSSION}

\section{Impact of PBZ on the Growth of Clonal Oil Palms}

Clonal oil palms were treated with a range of PBZ concentrations (from 10 to $100 \mathrm{mg}$ litre $^{-1}$ ) at weekly intervals for six weeks and then allowed to recover for the following eight weeks. Foliar spray application of PBZ to clonal oil palms resulted in a rapid reduction in plant height compared to the controls (Figures 1 and 2). A significant decline in growth rate could be detected within one week

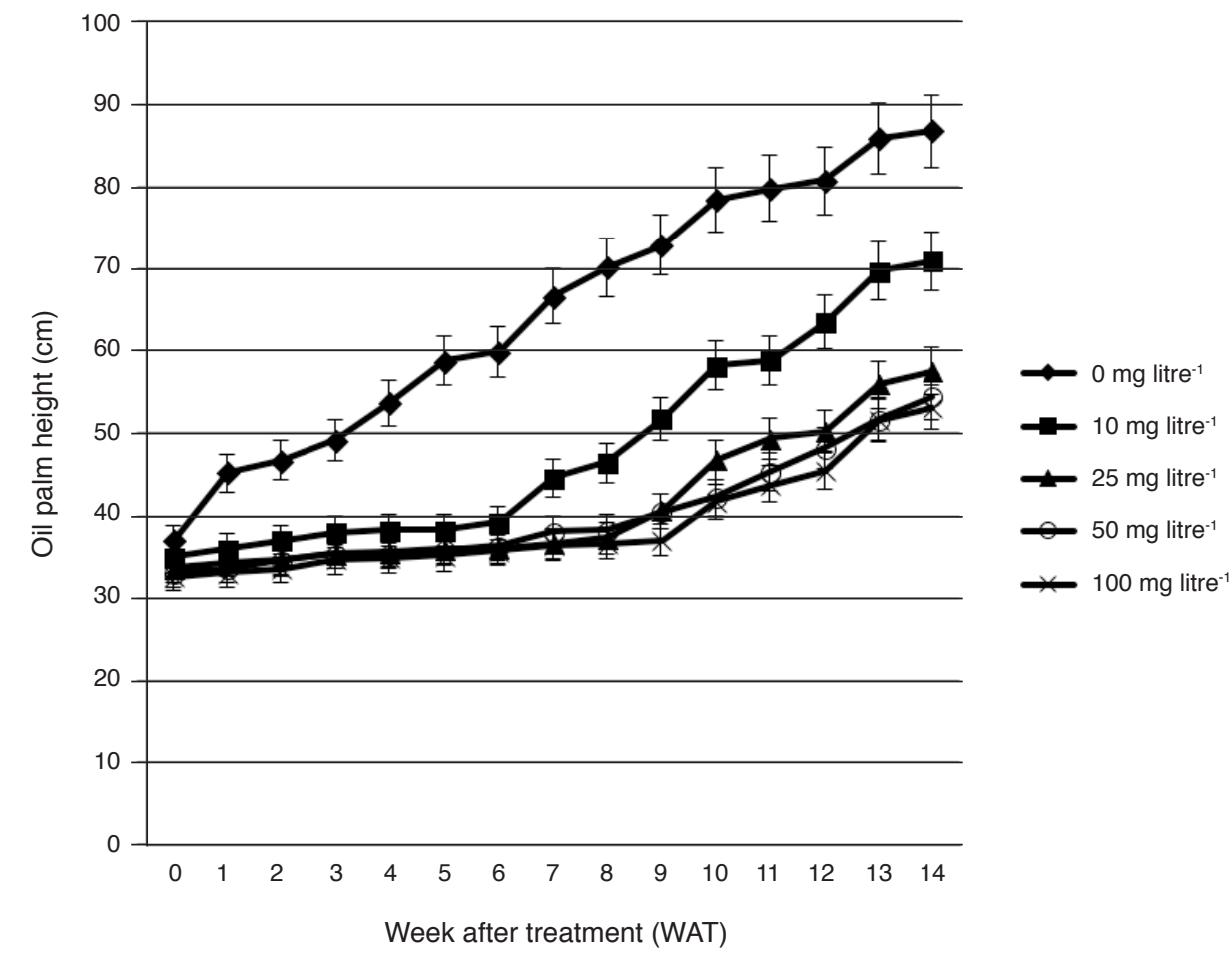

Figure 1. Height of clonal oil palms after treatment with different concentrations of paclobutrazol (PBZ). Plants were exposed to PBZ once a week for the first six weeks and then allowed to recover from week 7 . Range represents standard error $(n=5)$. 

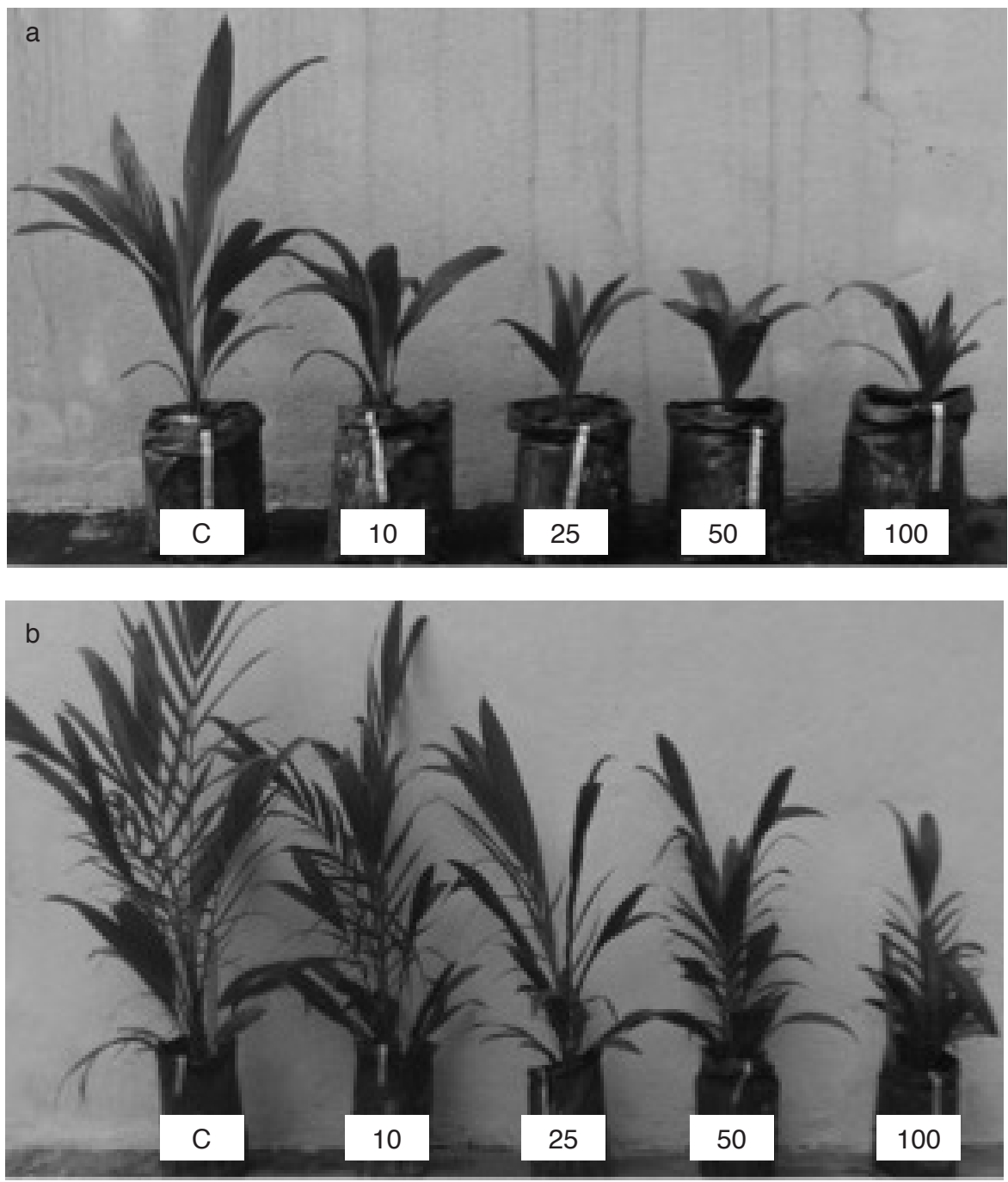

Figure 2. The impact of different concentrations of paclobutrazol (PBZ) on the growth and development of clonal oil palm (a) six weeks after first treatment and (b) 14 weeks after first treatment. Palms were sprayed with water $(C)$ or PBZ at weekly intervals for six weeks at concentrations of: $10 \mathrm{mg} \mathrm{litre}^{-1}$; $25 \mathrm{mg} \mathrm{litre}^{-1}$; $50 \mathrm{mg} \mathrm{litre}^{-1}$; or $100 \mathrm{mg}_{\text {litre }}$. $^{-}$.

of PBZ application in all plants and this was most pronounced in response to the higher concentrations (50 and $100 \mathrm{mg} \mathrm{litre}^{-1}$ ) of the chemical (Table 1). The impact of PBZ on plant height was also apparent within a week of first application and over the six treatment weeks there was no significant difference in the inhibitory effect on growth between the three higher concentrations of the chemical (Figure 1). By week 6 the height of PBZ-treated palms ranged from $79 \%-88 \%$ of control plants. By week 7 , one week after PBZ treatment had ceased the growth rate of oil palms previously exposed to $10 \mathrm{mg}$ litre $^{-1}$ had begun to recover although they continued to be slower than that of the controls (Table 1). The rate of growth of oil palm clones exposed to concentrations of PBZ greater than $10 \mathrm{mg}^{\text {litre }}{ }^{-1}$ continued to be reduced until week 13 , however, at this time only oil palm clones exposed to the highest concentration of PBZ (100 mg litre $\left.{ }^{-1}\right)$ were significantly lower than the controls. By week 14, although growth rates of PBZ-treated clones had largely returned to control values, their overall heights remained significantly lower (Figure 1).

It is well documented that PBZ treatment inhibits the production of GA leading to a depletion of these important plant growth regulators in plant cells (Ryan et al., 2011). The compound acts by inhibiting the enzymes involved in regulating the first three steps in the terpenoid pathway associated with GA biosynthesis (Chaney, 2004). This is the first report that PBZ can reduce the growth of clonal oil palms, however, it has been reported that this GA biosynthesis inhibitor can act as a growthretardant when applied to date palm (Cohen et al., 2013) and a number of dicot tree species (Tanis et al., 2015). Similar observations have been reported by Wahyuni et al. (2011) on the effect of the plant growth retardant on Brunonia and Calandrinia sp. and that plants treated with PBZ grew shorter compared to the normal untreated plant.

Previous study showed that the inhibitory effects of PBZ on date palm were apparent within a 
TABLE 1. GROWTH RATE OF CLONAL OIL PALMS TREATED WITH DIFFERENT CONCENTRATIONS OF PACLOBUTRAZOL (PBZ) COMPARED TO UNTREATED CONTROL PLANTS

\begin{tabular}{|c|c|c|c|c|c|}
\hline WAT & Control & $10 \mathrm{mg}$ litre $^{-1}$ & $25 \mathrm{mg}$ litre $^{-1}$ & 50 mg litre ${ }^{-1}$ & $100 \mathrm{mg}$ litre $^{-1}$ \\
\hline $1-2$ & $2.18 \pm 1.4 \mathrm{a}$ & $1.02 \pm 1.0 \mathrm{~b}$ & $1.08 \pm 1.2 b$ & $0.34 \pm 0.2 \mathrm{c}$ & $0.48 \pm 0.2 \mathrm{c}$ \\
\hline $2-3$ & $2.4 \pm 1.6 a$ & $0.94 \pm 0.6 b$ & $1.1 \pm 0.4 b$ & $1.04 \pm 0.7 b$ & $0.68 \pm 0.5 c$ \\
\hline $3-4$ & $4.6 \pm 1.8 \mathrm{a}$ & $0.42 \pm 0.2 b$ & $0.48 \pm 0.6 b$ & $0.3 \pm 0.2 b$ & $0.42 \pm 0.3 b$ \\
\hline $4-5$ & $5.14 \pm 2.4 \mathrm{a}$ & $0.16 \pm 0.1 b$ & $0.22 \pm 0.1 b$ & $0.34 \pm 0.2 b$ & $0.24 \pm 0.1 b$ \\
\hline $5-6$ & $1.6 \pm 0.5 a$ & $0.66 \pm 0.5 b$ & $0.28 \pm 0.2 b$ & $0.32 \pm 0.1 b$ & $0.3 \pm 0.2 b$ \\
\hline $6-7$ & $4.78 \pm 2.2 \mathrm{a}$ & $3.3 \pm 1.0 \mathrm{~b}$ & $0.56 \pm 0.5 c$ & $0.34 \pm 0.1 \mathrm{c}$ & $0.32 \pm 0.1 c$ \\
\hline $7-8$ & $3.92 \pm 1.3 a$ & $2.18 \pm 0.6 b$ & $0.86 \pm 0.6 \mathrm{c}$ & $0.18 \pm 0.1 c$ & $0.18 \pm 0.1 \mathrm{c}$ \\
\hline $8-9$ & $4.72 \pm 1.2 \mathrm{a}$ & $3.06 \pm 0.8 b$ & $2.82 \pm 1.6 \mathrm{~b}$ & $2.04 \pm 0.5 c$ & $0.46 \pm 0.2 \mathrm{~d}$ \\
\hline $9-10$ & $5.48 \pm 1.5 a$ & $5.52 \pm 1.3 a$ & $5.94 \pm 0.9 a$ & $2.44 \pm 0.7 \mathrm{~b}$ & $3.84 \pm 0.6 \mathrm{c}$ \\
\hline $10-11$ & $2.28 \pm 0.8 \mathrm{a}$ & $2.7 \pm 0.9 a$ & $2.04 \pm 1.0 \mathrm{a}$ & $1.12 \pm 0.7 \mathrm{~b}$ & $1.36 \pm 0.2 b$ \\
\hline $11-12$ & $4.14 \pm 0.9 a$ & $2.58 \pm 0.8 b$ & $1.64 \pm 0.8 \mathrm{c}$ & $1.14 \pm 0.4 \mathrm{c}$ & $1.6 \pm 0.6 \mathrm{c}$ \\
\hline $12-13$ & $5.16 \pm 1.1 \mathrm{a}$ & $4.68 \pm 0.8 \mathrm{a}$ & $5.16 \pm 1.8 \mathrm{a}$ & $4.6 \pm 1.8 \mathrm{a}$ & $3.34 \pm 0.7 b$ \\
\hline
\end{tabular}

Note: *A different letter of the alphabet indicates a significant difference at $p=0.05$. WAT - week after first treatment.

few weeks of treatment. However, in contrast to our data, which showed that clonal oil palms recovered within a few weeks of treatment cessation, the effects on the elemental growth rate of date palm spears persisted for many months after application of PBZ (Cohen et al., 2013). It has also been suggested that the effectiveness for inhibition of shoot and leaf growth by PBZ is determined by the concentration of the chemical used, the plant species under study, and its stage of development (Chaney, 2004; Lee et al., 1998). Clonal oil palms are particularly responsive to PBZ but are able to undergo rapid recovery after treatment has ceased which suggests that they may be efficient metabolisers of the chemical.

There were no significant differences in oil palm stem diameter between control and PBZ-treated plants six weeks after the first treatment with the stem diameter ranging from $1.4 \mathrm{~cm}$ to $1.6 \mathrm{~cm}$. However, PBZ treated plants did show a reduction in stem diameter 14 weeks after treatment with the stem diameters ranging from $2.7 \mathrm{~cm}$ to $2.0 \mathrm{~cm}$. Exposure of palms to the highest concentration of PBZ (100 mg litre ${ }^{-1}$ ) resulted in stems being $25.9 \%$ narrower than the controls (Table 2). Hence, in addition to the reduction in oil palm height, PBZ treatment also affected the stem diameter. A reduction in shoot radial growth of Fraxinus species after PBZ treatment has been previously reported by Tanis et al. (2015). Similarly, in linseed (Linum usitatissimum L.), PBZ treatment caused a reduction of stem diameter (Ryan et al., 2011) although Tsegaw et al. (2005) found that the chemical made potato plants grow shorter but with thicker stems compared to the control.

Impact of PBZ on Chlorophyll Index and Photosynthetic Rate of Clonal Oil Palms

Clonal oil palms treated with the two highest concentrations of PBZ (50 mg litre ${ }^{-1}$ and $100 \mathrm{mg}$ litre $^{-1}$ ) were much darker green than the controls. Analysis of leaf tissues revealed that they exhibited a net photosynthesis rate with an average mean value of $15.6 \mu \mathrm{mol} \mathrm{CO} \mathrm{m}^{-2} \mathrm{~s}^{-1}$ and this was more than $16 \%$ greater than the water-treated palms (Table 3 ). Palms exposed to these PBZ treatments also showed a significantly higher mean of chlorophyll index per unit area of leaf tissue ranging from 59.5 to 63.5 compared to the control value of 55.5 (Table 3). At the two lower PBZ concentrations of 10 and $25 \mathrm{mg}$ litre $^{-1}$ photosynthetic rate and chlorophyll index of clonal palms were indistinguishable from the controls.

An increased photosynthetic rate in Catharanthus roseus (Abdul Jaleel et al., 2007) and potato (Tsegaw et al., 2005) exposed to PBZ has been reported previously and this was attributed to a higher chlorophyll content of the leaf tissue. The relationship between chlorophyll index and net photosynthetic

TABLE 2. STEM DIAMETER OF CLONAL OIL PALMS SIX AND 14 WEEKS AFTER TREATMENT WITH DIFFERENT CONCENTRATIONS OF PACLOBUTRAZOL (PBZ)

\begin{tabular}{|c|c|c|c|c|c|}
\hline Parameter & $\begin{array}{l}\text { Control } \\
\text { litre }^{-1}\end{array}$ & $\begin{array}{c}\text { PBZ } \\
10 \text { mg litre }^{-1}\end{array}$ & $\begin{array}{c}\text { PBZ } \\
25 \text { mg litre }^{-1}\end{array}$ & $\begin{array}{c}\text { PBZ } \\
50 \mathrm{mg} \mathrm{litre}^{-1}\end{array}$ & $\begin{array}{c}\text { PBZ } \\
100 \mathrm{mg}^{\text {litre }}{ }^{-1}\end{array}$ \\
\hline $\begin{array}{l}\text { Stem diameter } \\
\text { at } 6 \text { WAT }(\mathrm{cm})\end{array}$ & $1.5 \pm 0.02 \mathrm{a}$ & $1.6 \pm 0.01 \mathrm{a}$ & $1.4 \pm 0.04 a$ & $1.6 \pm 0.02 \mathrm{a}$ & $1.6 \pm 0.04 a$ \\
\hline $\begin{array}{l}\text { Stem diameter } \\
\text { at } 14 \text { WAT }(\mathrm{cm})\end{array}$ & $2.7 \pm 0.09 \mathrm{a}$ & $2.4 \pm 0.06 \mathrm{~b}$ & $2.2 \pm 0.06 \mathrm{bc}$ & $2.1 \pm 0.05 \mathrm{~cd}$ & $2.0 \pm 0.09 \mathrm{~d}$ \\
\hline
\end{tabular}

Note: ${ }^{*}$ A different letter of the alphabet indicates a significant difference at $\mathrm{p}=0.05$. WAT - week after first treatment. 
TABLE 3. EFFECT OF DIFFERENT CONCENTRATIONS OF PACLOBUTRAZOL (PBZ) ON OIL PALM NET PHOTOSYNTHESIS RATE AND RELATIVE CHLOROPHYLL INDEX AT SIX WEEKS AFTER FIRST TREATMENT (WAT)

\begin{tabular}{|c|c|c|c|c|c|}
\hline Parameter & Control & $\begin{array}{c}\text { PBZ } \\
10 \text { mg litre }^{-1}\end{array}$ & $\begin{array}{c}\text { PBZ } \\
25 \mathrm{mg} \mathrm{litre}^{-1}\end{array}$ & $\begin{array}{c}\text { PBZ } \\
50 \mathrm{mg}^{\text {litre }}{ }^{-1}\end{array}$ & $\begin{array}{c}\text { PBZ } \\
100 \mathrm{mg} \mathrm{litre}^{-1}\end{array}$ \\
\hline $\begin{array}{l}\text { Photosynthesis rate } \\
\left(\mu \mathrm{mol} \mathrm{CO} \mathrm{m}^{-2} \mathrm{~s}^{-1}\right)\end{array}$ & $13.1 \pm 0.1 \mathrm{a}$ & $13.7 \pm 0.3 \mathrm{a}$ & $14.1 \pm 0.3 a$ & $15.6 \pm 0.2 b$ & $15.6 \pm 0.1 b$ \\
\hline Chlorophyll index & $55.5 \pm 3.8 \mathrm{a}$ & $57.8 \pm 2.3 a$ & $56.2 \pm 1.9 \mathrm{a}$ & $59.5 \pm 2.7 \mathrm{~b}$ & $63.5 \pm 3.5 c$ \\
\hline
\end{tabular}

Note: *A different letter of the alphabet indicates a significant difference at $\mathrm{p}=0.05$.

rate of PBZ-treated plants is shown in Figure 3. The relationship between these two parameters is linear with an $\mathrm{R}^{2}$ value of 0.795 . According to Kumar et al. (2012), the elevation in the rate of photosynthesis in PBZ-treated Camelina sativa is the direct result of an increase in photosynthetic pigments such as chlorophyll $a$ and $b$, and carotenoids in leaf tissues. However, it has also been proposed that PBZ treatment may enhance the water use efficiency or gaseous exchange of leaves which might also contribute to an elevation in net photosynthesis of plant tissues (Gnanasiri et al., 1995; Rhadha et al., 2007).

\section{Stomatal Conductance and Transpiration Rate}

The effect of PBZ on the oil palm stomatal conductance (Gs) and transpiration rate (Tr) is shown in Table 4. Six weeks after first exposure to PBZ, Gs was significantly lower in the treated

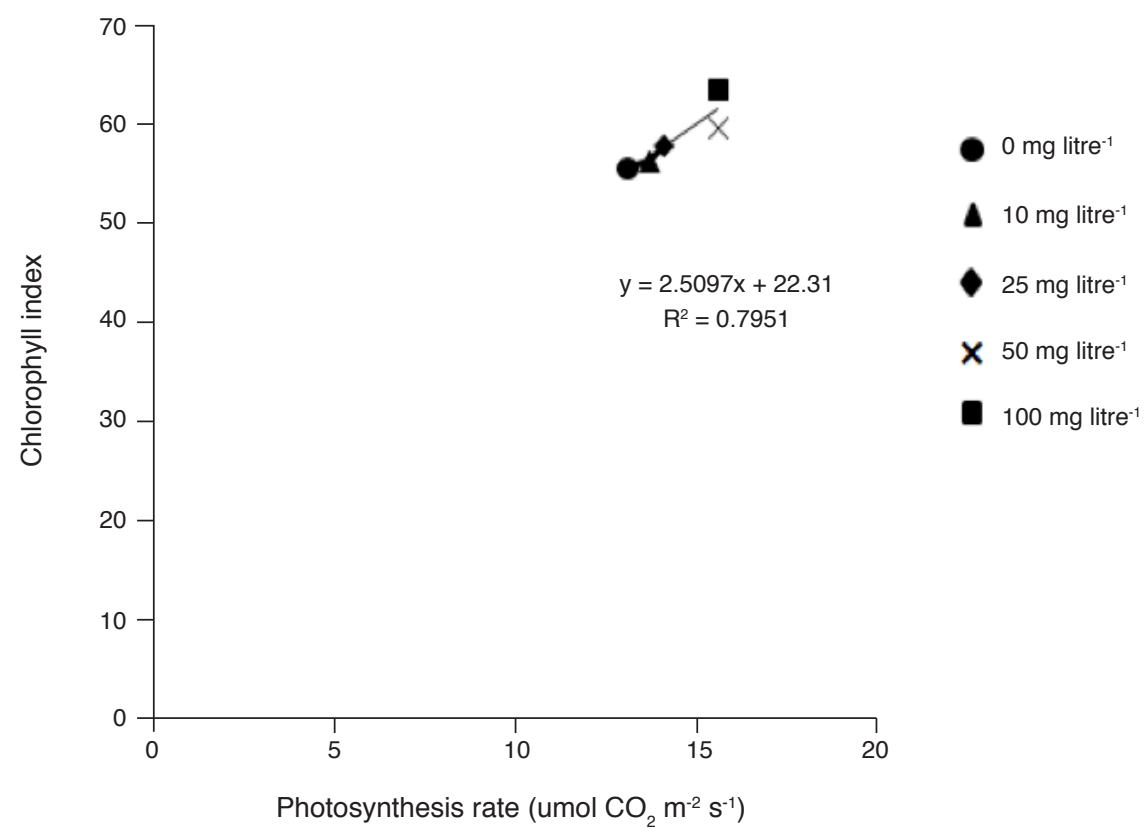

Figure 3. Correlation between relative chlorophyll index and net photosynthesis rate of clonal oil palms treated with different concentration of paclobutrazol (PBZ). Each data point represents the mean of five replicates. Measurements were taken six weeks after first treatment.

TABLE 4. EFFECT OF DIFFERENT CONCENTRATIONS OF PACLOBUTRAZOL (PBZ) ON OIL PALM STOMATAL CONDUCTANCE AND TRANSPIRATION RATE AT SIX WEEKS AFTER FIRST TREATMENT (WAT)

\begin{tabular}{|c|c|c|c|c|c|}
\hline Parameter & Control & $\begin{array}{c}\text { PBZ } \\
10 \mathrm{mg} \mathrm{litre}^{-1}\end{array}$ & $\begin{array}{c}\text { PBZ } \\
25 \text { mg litre }^{-1}\end{array}$ & $\begin{array}{c}\text { PBZ } \\
50 \mathrm{mg} \mathrm{litre}^{-1}\end{array}$ & $\begin{array}{c}\text { PBZ } \\
100 \mathrm{mg} \mathrm{litre}^{-1}\end{array}$ \\
\hline $\begin{array}{l}\text { Stomatal } \\
\text { conductance (mmol } \\
\left.\mathrm{H}_{2} \mathrm{O} \mathrm{m}^{-2} \mathrm{~s}^{-1}\right)\end{array}$ & $0.27 \pm 0.1 \mathrm{a}$ & $0.17 \pm 0.1 b$ & $0.21 \pm 0.1 \mathrm{c}$ & $0.20 \pm 0.1 \mathrm{c}$ & $0.19 \pm 0.1 b c$ \\
\hline 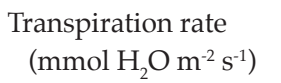 & $2.12 \pm 0.0 \mathrm{a}$ & $2.34 \pm 0.08 \mathrm{a}$ & $2.36 \pm 0.11 \mathrm{a}$ & $2.70 \pm 0.11 \mathrm{a}$ & $2.8 \pm 0.09 a$ \\
\hline
\end{tabular}

Note: *A different letter of the alphabet indicates a significant difference at $\mathrm{p}=0.05$. 
palms with the average mean ranging from 0.27 in the control to $0.17 \mathrm{~mol} \mathrm{H}_{2} \mathrm{O} \mathrm{m} \mathrm{m}^{-2} \mathrm{~s}^{-1}$ after chemical treatment. The effect of PBZ on stomatal conductance was not dose dependent with the lowest concentration tested in these experiments (10 $\mathrm{mg}$ litre $\left.^{-1}\right)$ being as effective as the highest (100 mg litre ${ }^{-1}$ ). Surprisingly, the rate of transpiration of oil palm leaves was not significantly affected by the PBZ treatment, indeed there was a general trend of an elevation after PBZ application (Table 4) with the means varying between 2.12 and $2.8 \mu \mathrm{mol} \mathrm{m}^{-2}$ $\mathrm{s}^{-1}$. The decrease in Gs and slight elevation in $\operatorname{Tr}$ in the PBZ treated oil palm contributed to the change in net photosynthetic rate observed in this study. The results presented here show agreement with those reported by Rhadha et al. (2007) who studied the responses of Setaria italica to PBZ treatment. Collectively our findings show that application of PBZ to oil palm not only has direct effects on plant growth but also on the efficiency of gaseous exchanges in plant tissues.

\section{Leaf Anatomy}

Application of PBZ to clonal oil palm resulted in modifications to the anatomy of the leaf tissues compared to the control (Figure 4). In particular, leaves treated with the GA-biosynthetic inhibitor at a concentration of $25 \mathrm{mg}$ litre $^{-1}$ or higher were comprised of palisade mesophyll cells with a cross
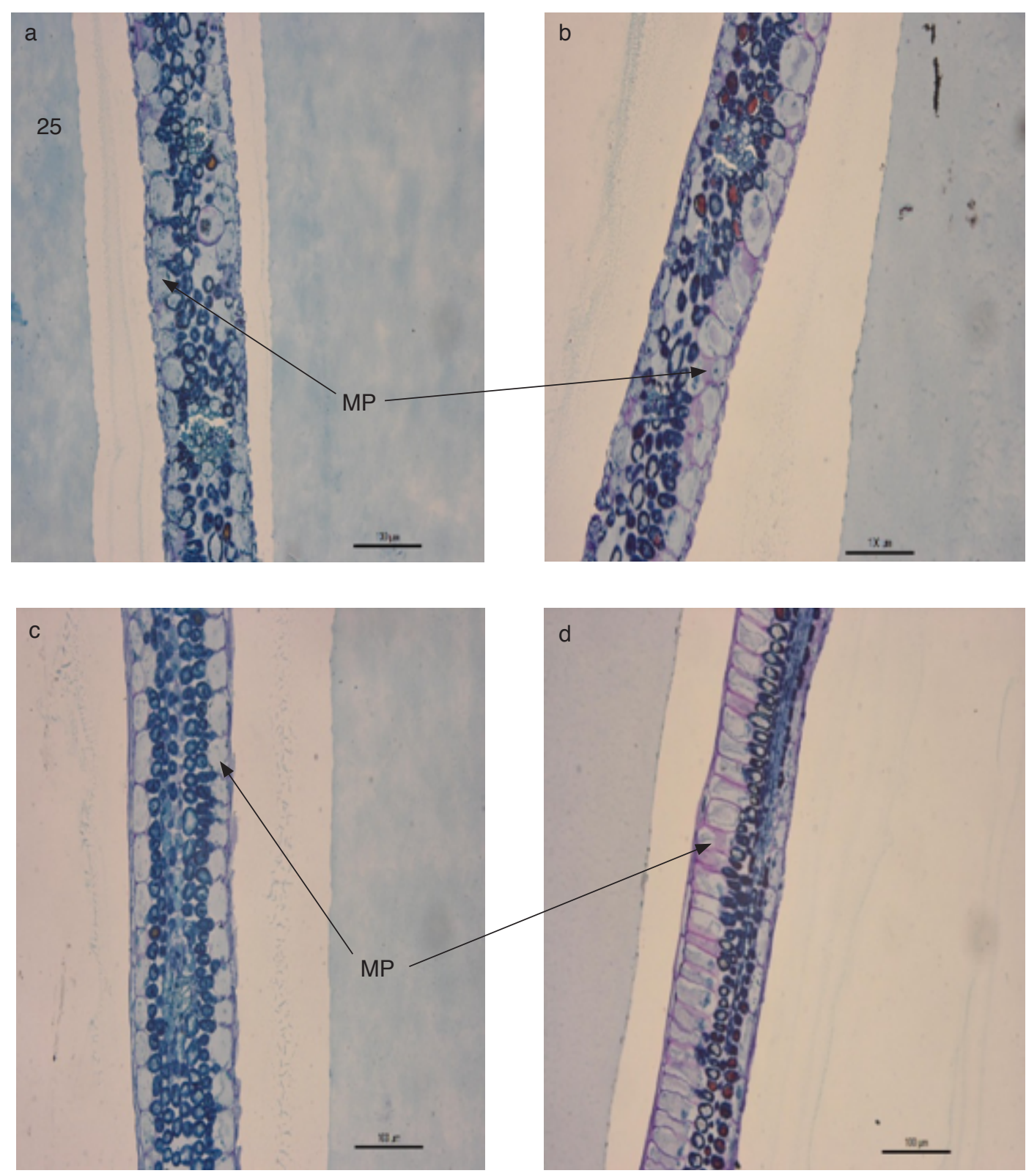

Figure 4. Anatomy of oil palm leaf tissue after treatment with water (a) and (c); or $50 \mathrm{mg} \mathrm{litre-1} \mathrm{paclobutrazol} \mathrm{(b)} \mathrm{and} \mathrm{(d)} \mathrm{for} \mathrm{six} \mathrm{weeks} \mathrm{and} \mathrm{all}$ tissues were collected at six weeks after first treatment. Transverse sections shown in (a) and (b) and longitudinal sections shown in (c) and (d). MP - Mesophyll palisade. Scale bar $=100 \mu m$. 
sectional diameter from $9.8 \%$ to $12.1 \%$ higher than the controls. As a consequence, the number of cells per unit area was substantially smaller (Table 5). In contrast, the longitudinal dimension of the palisade mesophyll cells was reduced by as much as $34 \%$ in comparison to the controls (Table 5). The number of cells in leaf tissues per unit area was also reduced in response to the PBZ treatment by $24.7 \%$ to $31.1 \%$ depending on the concentration of the chemical applied. Abdul Jaleel et al. (2007) reported an increase in the number of mesophyll palisade cell per unit area in C. roseus in response to PBZ treatment and proposed that this was the consequence of the compound promoting the formation of additional layers of mesophyll palisade cell. Treatment of potato plants with PBZ was found to increase both the length and the width of palisade cells (Tsegaw et al., 2005) and this contributed to an observed thickening of the leaf. Thicker leaves have also been reported in Chrysanthemum plants after exposure to PBZ and this seems to be the consequence of the production of an additional layer of mesophyll cells rather than an increase in individual cell size as treated plants exhibited mesophyll cells that were smaller and more tightly packed (Burrows et al., 1992).

\section{Stem Anatomy}

PBZ treatment resulted in shorter and smaller cortical cells in the oil palm stems compared to the untreated palm (Table 6). The mean cell diameter declined from 46.4 to $41.4 \mu \mathrm{m}$ while the mean cell length was reduced from 61.4 to $36.1 \mu \mathrm{m}$ in stems from plants exposed to the highest concentration of the chemical compared to the controls. In addition, the number of cell per unit area increased in PBZ treated oil palm due to the smaller diameter of the cells. These results were consistent with previous reports on the effect of this plant growth regulator on stem tissues where in linseed PBZ treatment caused a reduction in the diameter of xylem, phloem and other tissues compared to the control (Ryan et al., 2011).

In addition, stem cells from PBZ treated oil palms showed a greatly enhanced quantity of starch granules compared to the control (Figures $5 c$ and $5 d$ ). Plant growth retardants, such as PBZ, have been reported to promote the starch content of cassava (Medina et al., 2012) and potato (Tsegaw et al., 2005) and it has been proposed that this is the consequence of a reduction in the levels of bioactive GAs in the cells. According to Appeldoorn et al. (1997),

TABLE 5. THE EFFECT OF DIFFERENT CONCENTRATIONS OF PACLOBUTRAZOL (PBZ) ON CELL SIZE AND CELL NUMBER PER UNIT AREA IN OIL PALM LEAVES AT SIX WEEKS AFTER FIRST TREATMENT (WAT)

\begin{tabular}{|c|c|c|c|c|c|}
\hline Parameter & Control & $\begin{array}{c}\text { PBZ } \\
10 \text { mg litre }^{-1}\end{array}$ & $\begin{array}{c}\text { PBZ } \\
25 \text { mg litre }^{-1}\end{array}$ & $\begin{array}{c}\text { PBZ } \\
50 \mathrm{mg} \mathrm{litre}^{-1}\end{array}$ & $\begin{array}{c}\text { PBZ } \\
100 \mathrm{mg}^{\text {litre }} \mathrm{e}^{-1}\end{array}$ \\
\hline $\begin{array}{l}\text { Palisade cell } \\
\quad \text { diameter }(\mu \mathrm{m})\end{array}$ & $33.6 \pm 0.5 a$ & $36.9 \pm 0.5 \mathrm{a}$ & $42.2 \pm 0.2 b$ & $45.7 \pm 0.4 \mathrm{bc}$ & $47.8 \pm 0.5 \mathrm{c}$ \\
\hline $\begin{array}{l}\text { Palisade cell } \\
\text { length }(\mu \mathrm{m})\end{array}$ & $44.6 \pm 0.7 a$ & $34.3 \pm 0.5 b$ & $34.5 \pm 0.7 \mathrm{~b}$ & $33.2 \pm 0.5 b$ & $33.7 \pm 0.6 b$ \\
\hline $\begin{array}{l}\text { Numbers of cells } \\
\text { unit area }{ }^{-1} \\
(200 \mu \mathrm{m} \times 200 \mu \mathrm{m})\end{array}$ & $15 \pm 0.3 \mathrm{a}$ & $11.6 \pm 0.2 b$ & $11.0 \pm 0.4 \mathrm{~b}$ & $11.0 \pm 0.3 b$ & $10.3 \pm 0.4 b$ \\
\hline
\end{tabular}

Note: ${ }^{*} \mathrm{~A}$ different letter of the alphabet indicates a significant difference at $\mathrm{p}=0.05$.

TABLE 6. THE EFFECT OF DIFFERENT CONCENTRATIONS OF PACLOBUTRAZOL (PBZ) ON CELL SIZE AND CELL NUMBER PER UNIT AREA IN OIL PALM STEMS AT SIX WEEKS AFTER FIRST TREATMENT (WAT)

\begin{tabular}{|c|c|c|c|c|c|}
\hline Parameter & Control & $\begin{array}{c}\text { PBZ } \\
10 \mathrm{mg} \mathrm{litre}^{-1}\end{array}$ & $\begin{array}{c}\text { PBZ } \\
25 \mathrm{mg} \mathrm{litre}^{-1}\end{array}$ & $\begin{array}{c}\text { PBZ } \\
50 \mathrm{mg} \mathrm{litre}^{-1}\end{array}$ & $\begin{array}{c}\text { PBZ } \\
100 \mathrm{mg} \mathrm{litre}^{-1}\end{array}$ \\
\hline $\begin{array}{l}{ }^{*} \text { Cortical cell } \\
\quad \text { diameter }(\mu \mathrm{m})\end{array}$ & $46.4 \pm 0.3 a$ & $44.3 \pm 0.6 \mathrm{ab}$ & $43.0 \pm 0.4 \mathrm{ab}$ & $41.4 \pm 0.4 b$ & $41.4 \pm 0.3 b$ \\
\hline $\begin{array}{l}{ }^{*} \text { Cortical cell } \\
\text { length }(\mu \mathrm{m})\end{array}$ & $61.4 \pm 0.7 a$ & $43.3 \pm 0.6 b$ & $42.0 \pm 0.2 b$ & $40.9 \pm 0.8 b c$ & $36.1 \pm 0.5 c$ \\
\hline $\begin{array}{l}{ }^{*} \text { Number of cells } \\
\quad \text { unit area }{ }^{-1} \\
\quad(200 \mu \mathrm{m} \times 200 \mu \mathrm{m})\end{array}$ & $42.3 \pm 1.3 a$ & $53.7 \pm 0.5 b$ & $55.7 \pm 0.5 b$ & $56.3 \pm 1.6 b$ & $60.6 \pm 2.2 b$ \\
\hline
\end{tabular}

Note: * A different letter of the alphabet indicates a significant difference at $\mathrm{p}=0.05$. 

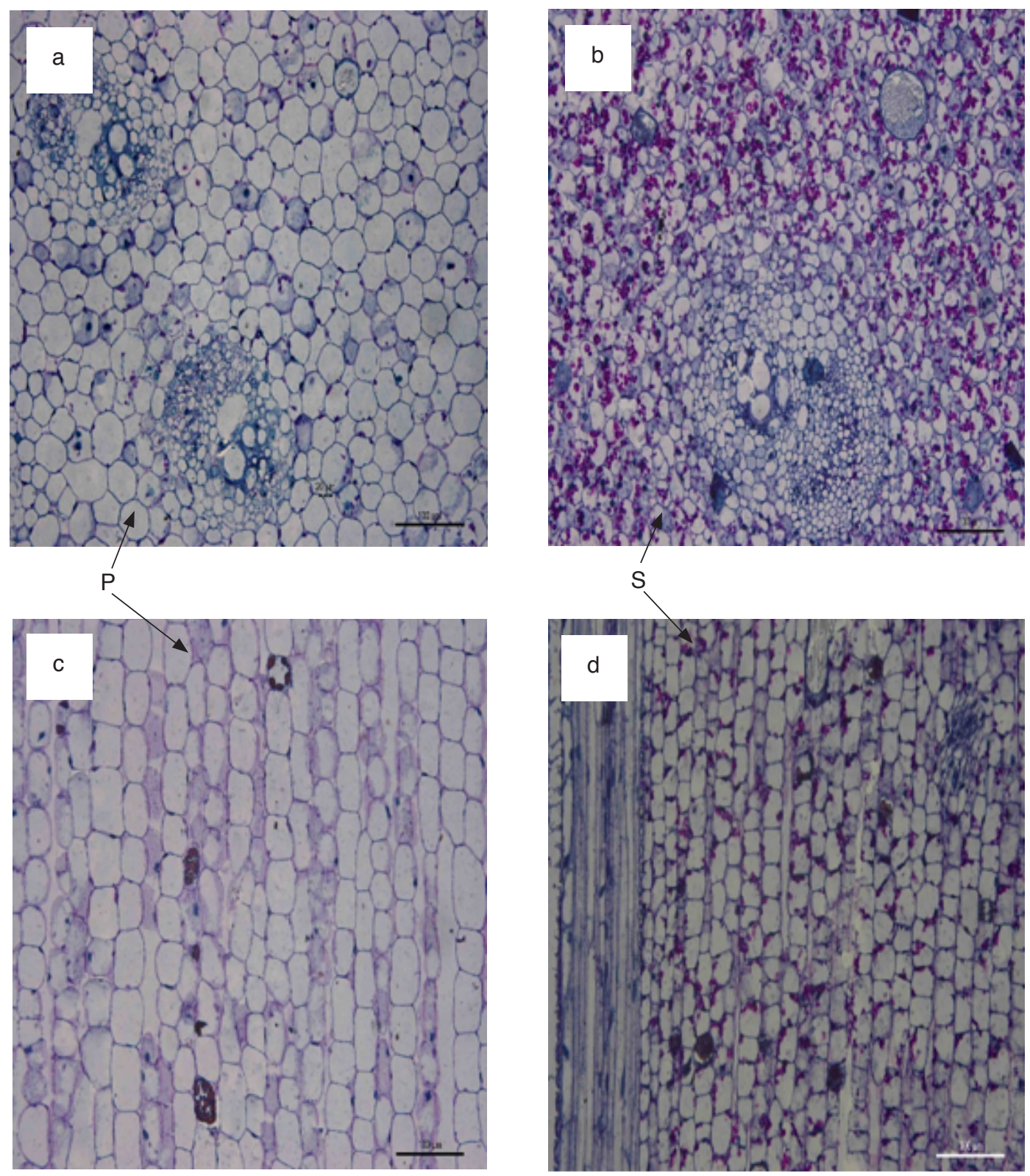

Figure 5. Anatomy of oil palm stem tissue after treatment with water (a) and (c); or $50 \mathrm{mg}$ litre-1 paclobutrazol (b) and (d) for six weeks and all tissues were collected at six weeks after treatment. Transverse sections shown in (a) and (b) and longitudinal sections shown in (c) and (d). P - parenchyma cells; S - starch granule. Scale bar $=100 \mu \mathrm{m}$.

the reduction of active GA leads to an increase of enzymes, such as ADPG- pyrophoshorylase, that stimulates the production of starch.

\section{CONCLUSION}

The results of this investigation demonstrate that application of the GA biosynthesis inhibitor PBZ rapidly inhibits elongation growth of clonal oil palm. The effect is concentration dependent and the growth rate of plants recovers soon after application of PBZ ceases. The impact of PBZ can be seen at a cellular level where the cell size of palisade cells within the leaves and cortical parenchyma within the stem are substantially reduced. Plants treated with the chemical exhibit elevated levels of chlorophyll and have a higher photosynthetic rate. These effects may be partially a consequence of attenuation in stomatal conductance and rate of transpiration in leaf tissues. Our observations indicate that it may be possible to manipulate oil palm height by regulating either GA biosynthesis or the signalling of this plant growth regulator by chemical or genetic means. This may prove to be a valuable strategy to enhance harvesting efficiency; however, further work is necessary to determine the impact of modifying GA levels on flowering and fruit development. 


\section{ACKNOWLEDGEMENT}

The authors would like to thank the DirectorGeneral of MPOB for permission to publish this article. We appreciate the help of Dr Abrizah Othman and Dr Abdul Masani Mat Yunus for critically reviewing this manuscript. We also would like to thank Khairul Anuar Rahman and Rosna Angsor for their technical assistance.

\section{REFERENCES}

ABDUL JALEEL, C; MANIVANNAN, P; SANKAR, B; KISHOREKUMAR, A; SANKARI, S and PANNEERSELVAM, R (2007). Paclobutrazol enhances photosynthesis and ajmalicine production in Catharanthus roseus. Process Biochemistry, 42: 15661570.

APPELDOORN, N J G; DE BRUIJN, S M; KOOT-GRONSVELD, E A M; VISSER, R G F; VREUGDENHIL, D and VAN DER PLAS, L H W (1997). Developmental changes of enzymes involved in conversion of sucrose to hexose-phosphate during early tuberisation of potato. Planta, 202: 220-226.

BEROVA, M and ZLATEV, Z (2000). Physiological response and yield of Paclobutrazol treated tomato plants (Lycopersicon esculentum Mill.). Plant Growth Regulation, 30: 117-123.

BURROWS, E; BOAG, T S and STEWART W P (1992). Changes in leaf, stem, and root anatomy of Chrysanthemum cv. Lillian Hoek following paclobutrazol application. J. Plant Growth Regulation, 11: 189-194.

CHANEY, WR (2004). Paclobutrazol: More than Just a Growth Retardant. Pro-Hort Conference. Peoria, Illinois.

COHEN, Y; ALONI, D D; ADUR, U; HAZON, H and KLEIN, J D (2013). Characterization of growthretardant effects on vegetative growth of date palm seedlings. J. Plant Growth Regulation, 32: 533-541.

CORLEY, R H V and TINKER, P B (2003). The Oil Palm. Fourth edition. Blackwell Science Ltd, Oxford.

DAVIÉRE, J M and ACHARD, P (2013). Gibberelin signalling in plants. Development, 140: 1147-1151.

ELMAR, W and FRANK, W (2010). Histology and research at the hard tissue-implant interface using Technovit 9100 new embedding technique. Acta Biomaterialia: 4447-4455.

FLEET, C M and SUN, T (2005). A DELLA cate balance: the role of gibberellin in plant morphogenesis. Current Opinion in Plant Biology, 8: 77-85.

GNANASIRI, S P; CHANEY, W R and HOLT, H H (1995). Gas exchange and water relations of Fraxinus americana affected by flurprimidol. Tree Physiology, 17: 97-103.

HAQUE, S; FAROOQI, A H A; GUPTA, M M; SANGWAN, R S and KHAN, A (2007). Effect of ethrel, chlormequat chloride and paclobutrazol on growth and pyrethrins accumulation in Chrysanthemum cinerariaefolium Vis. Plant Growth Regulation, 51: 263-269.

HEDDEN, P (2003). The genes of the green revolution. Trends in Genetics, 19: 5-9.

HEDDEN, P and PHILLIPS, A L (2000). Gibberellin metabolism: new insights revealed by the genes. Trends in Plant Science, 5: 523-530.

ITOH, H; UEGUCHI-TANAKA, M; SATO, Y; ASHIKARI, M and MATSUOKA, M (2002). The gibberellin signalling pathway is regulated by the appearance and disappearance of SLENDER RICE1 in nuclei. Plant Cell, 14: 57-70.

KOK, S-Y; ONG-ABDULLAH, M; EE C-L W and NAMASIVAYAM, P (2015). A histological study of oil palm (Elaeis guineensis) endosperm during seed development. J. Oil Palm Res. Vol. 27(2):107-112.

KUMAR, S; GHATTY, S; SATYANARAYANA, J; GUHA, A; CHAITANYA, B S K and REDDY, A $R$ (2012). Paclobutrazol treatment as a potential strategy for higher seed and oil yield in field-grown Camelina sativa L. Crantz. BMC Res. Notes: 1-13.

KUSHAIRI, A; RAJANAIDU, N; JALANI, B S and ZAKRI, A H (1999). Agronomic performance and genetic variability of dura $\times$ pisifera progenies. J. Oil Palm Res. Vol. 11: 1-24.

LEE, I; FOSTER, K R and MORGAN, P W (1998). Effect of gibberellin biosynthesis inhibitors on native gibberellin content, growth and floral initiation in Sorghum bicolor. Plant Growth Regulation, 17: 185195.

LUYINDULA, N; CORLEY, R HV and MANTANTU, N (2005), A comparison of the Deli Dumpy and Pobé Dwarf short-stemmed oil palms and their outcrossed progenies. J. Oil Palm Res. Vol. 17: 152-159.

MEDINA, R; BURGOS, A; DIFRANCO, V; MROGINSKI, L and CENÓZ, P (2012). Effects of chlorocholine chloride and paclobutrazol on cassava 
(Manihot esculenta Crantz cv. Rocha) plant growth and tuberous root quality. Agriscientia, 29: 51-58.

MONNA, L; KITAZAWA, N; YOSHINO, R; SUZUKI, J; MASUDA, H; MAEHARA, Y; TANJI, M; SATO, M; NASU, S and MINOBE, Y (2002). Positional cloning of rice semi dwarfing gene, sd1: rice "green revolution gene" encodes a mutant enzyme involved in gibberellin synthesis. DNA Research, 9: 11-17.

OLSZEWSKI, N; SUN, T P and GUBLER, F (2002). Gibberellin signalling: biosynthesis, catabolism, and response pathways. Plant Cell, 14: 61-80.

PAIVA, EAS; PINHO, S Z D and OLIVEIRA, D M $\mathrm{T}$ (2011). Large plant samples: how to process for GMA embedding? Light Microscopy, 689: 37-38.

RADEMACHER, W (2000). Growth retardants: effect on gibberellin biosynthesis and other metabolic pathways. Plant Physiology and Plant Molecular Biology, 51: 501-531.

RHADHA, B; SINGARIYA, P; MATHUR, N and BOHRA, S P (2007). Triazoles: their effects on net photosynthetic rate, transpiration rate and stomatal resistance in Setaria italica plants grown in vivo. Asian J. Exp. Sci, 21: 271-276.

RYAN, R; MCKENZIE, M K and DEYHOLOS, M K (2011). Effects of plant growth regulator treatments on stem vascular tissue development in linseed (Linum usitatissimum L.). J. Industrial Crops and Products, 34: 1119-1127.

SAKAMOTO, A; TSUKAMOTO, S; YAMAMOTO, $\mathrm{H}$; HASHIMOTO, M U; TAKAHASHI, M; SUZUKI, H and MORIKAWA, H (2003). Functional complementation in yeast reveals a protective role of chloroplast 2-Cys peroxiredoxin against reactive nitrogen species. The Plant J., 33: 841-851.

SASAKI, A; ASHIKARI, M; UEGUCHI-TANAKA, $\mathrm{M}$; ITOH, H; NISHIMURA, A; SWAPAN, D; ISHIYAMA, K; SAITO, T; KOBAYASHI, M; KHUSH, G S; KITANO, H and MATSUOKA, M (2002), Green revolution: a mutant gibberellin-synthesis gene in rice. Nature, 416: 701-702.

SENOO, S and ISODA, A (2003). Effects of paclobutrazol on dry matter distribution and yield in peanut. Plant Production Science, 6: 90-94.

SUN, T and GUBLER, F (2004). Molecular mechanism of gibberellin signaling in plants. Annual Review of Plant Biology, 55: 197-223.

TANIS, S R; MCCULLOUGH, D G and CREGG, B M (2015). Effect of paclobutrazol and fertilizer on the physiology, growth and biomass allocation of three Fraxinus species. Urban Forestry \& Urban Greening, 14: 590-598.

THOMAS, S G and SUN T (2004) Update on gibberellin signalling. A tale of the tall and the short. Plant Physiology, 135: 668-676.

TSEGAW, T; HAMMES, $S$ and ROBBERTSE, J (2005). Paclobutrazol-induced leaf, stem, and root anatomical modifications in potato. American Society for Horticultural Science, 40: 1343-1346.

WAHYUNI, S; KRISANTINI, S and JOHNSTON, M E (2011). Plant growth regulators and flowering of Brunonia and Calandrinia sp. Scientia Horticulturae, 128: 141-145. 